MICHAŁ IGIELSKI

\title{
Factors determining the development of SMEs in Poland in 2015-2020
}

\author{
"Passion for action \\ is not yet entrepreneurial". \\ Seneka
}

Michał Igielski Ph.D., Maritime University, Faculty of Management and Quality Science Gdynia, Poland, ORCID: 0000-0003-4680-3733.

\section{Introduction}

Turbulent economic environment, reinforced by unprecedented technological progress, ubiquitous globalization and global crises, such as the global pandemic COVID 19, are causing huge changes in national economic markets, including their main players companies. In the 21st century, against the background of ever-new economic challenges, the development of entrepreneurship has becomea basic condition for the sustainable development of each country. After all, it is its dynamics, regardless of differences in the understanding of its subject and subject structure in economic theory, that is an interpretation of economic growth and development.

Already A. Smith pointed out that economic development depends on the three prerogatives that the individual is entitled to - the pursuit of his own interests, the division of labour and freedom of trade. In economic practice, all of them are used, giving the opportunity to achieve the purpose for which economic entities are created (O'Rourke, 2009). 
Undertaking economic activity contributes to the revival and social and economic development of entire economies. It also manifests itself in reducing the level of unemployment and increasing revenues to state budgets. Therefore, as the main objective of the article, its author considered the identification of factors determining the development of SME enterprises in Poland in 2015-2020. Of course, due to the global pandemic, the research only covered the beginning of 2020. However, it is certainly worth returning to them, at the time of the "return to normality", as it is possible that most of the identified factors, have changed their value in the opinion of respondents.

An important element of the research work was to conduct surveys between 2015 and 2020, in 200 purposively selected SME companies that are based in Poland and were established no earlier than 2010. The information and opinions obtained in this way referred to the current situation of the enterprise and the assessment of the enterprise's development in the last 5-year period. Ina few cases, there were also opinions on the enterprise's development prospects in the coming years.

\section{The essence of entrepreneurship}

The term „entrepreneur" appeared in economic literature at the turn of the 17 th and 18th centuries, and it is derived from the French word "entrepreneur", which describes persons undertakinga certain activity. Suppliers, intermediaries and contractors, for example, began to be referred to as such. The word ",entreprendre", also derived from French, means to undertake. In French, we can also find the term "entreprenant”, which describesa bold, self-confident person, that is, one that has entrepreneurial qualities (Łochnicka, 2016).

However, the notion, through the continuous development of mankind, acquires more and more new characteristics. Already looking at the primitive people, we can see the beginnings of entrepreneurship - after all, their chances of survival depended largely on creativity, acquired skills and the idea of how to use these skills to hunt the animals or otherwise provide food for themselves and their loved ones. This feature perfectly fits the definition of entrepreneurship known today. By analyzing closer the development of man on earth, we can see the various forms of work, his own ventures, which he has undertaken over the centuries. It has always been necessary to look fora job that will meet the expectations of other people and, consequently, bringa measurable income. Profit is nowadays something we directly associate with entrepreneurship. 
R. Cantillon is considered to be the precursor of the term entrepreneurship in literature. He drew attention to traders seeking to make money by looking for cheap goods and selling them in places where they will geta higher price. He also pointed out thata typical businessman takes risks in order to make money which works perfectly well nowadays, because every attempt to make money on your own, to createa business always involves risk (Thornton, 2009).

Whereas according to S. Shane and S. Venkataraman (2003) there are all activities that consist of identifying, evaluating and exploiting opportunities to introduce new products and new services, or ways of organizing, new markets, and entrepreneurship itself consists of five elements:

- the existence of market opportunities - isa requirement for entrepreneurship,

- risk - an integral part of the entrepreneurial process,

- the existence of differences between those who cause different opportunities in the market,

- the entrepreneurial process requires organization in the sense of creating new combinations of resources,

- the entrepreneurial process requires innovation, notnecessarilya breakthrough. Analyzing the definitions described above, the author of the article noticed that entrepreneurship can be described in the simplest way as the art of coping with various life situations - it can be trained and learned. However, in the face of complex and rapidly changing reality, the entrepreneurship paradigm is more suitable for explaining contemporary phenomena. Instead of technocratic determinism, a paradigm ofa subjective, active role ofa person (entrepreneur), who is involved in the competition process through creativity and ingenuity, is proposed. Moreover, he acts under conditions of uncertainty (Kaliszczak \& Sieradzka, 2020).

As far as the person of an entrepreneur is concerned, J.B. Say (2012) claimed that an entrepreneur is the one who has his own enterprise - he owns or fully controls it. He isa person who is able to see the opportunities for development and is not afraid to risk it for profit. He introduceda division into types of entrepreneurs:

- industrial entrepreneur - uses natural factors to produce more valuable products,

- entrepreneur of the agricultural industry - the owner of arable land,

- entrepreneur of the handicraft industry - craftsman,

- entrepreneur of the commercial industry - merchant.

The approach to entrepreneurship as an attitude emphasizes the importance of entrepreneurial characteristics: personality, predisposition, general and 
market knowledge. These are also specific ways of reacting and being ready to take action. The attitude determines behavior and influences its effectiveness. Entrepreneurship is reflected ina creative and active pursuit of improvement of existing states of affairs and expresses readiness to take new actions or expand existing ones. Thus, it is aimed at achieving complex, multi-faceted material benefits. This results in increased income and improved working and living conditions. Entrepreneurial attitudes consist of three elements (Białasiewicz, 2016):

- emotional - moods and feelings,

- behavioral - predispositions to certain behaviors in certain situations,

- cognitive - information, opinions, knowledge, skills.

To sum up, since the initiation of the term entrepreneurship, its meaning has gradually but systematically changed. In fact, according to the author of the article, under the influence of external determinants, the meaning of its components that make up its meaning has changed. Nowadays, an entrepreneur is associated witha person who has an enterprise and is able to adapt to changing market conditions, which involves taking risks. Additionally, these people must, of course, be boldly committed and dynamic, which translates into an innovative attitude and creativity. They must be gifted with imagination, a feature that is necessary to plan and avoid bad consequences of their decisions. But on the other hand, it must be based on "common sense", because not every decision can be predicted. On the other hand, if bad actions are taken, entrepreneurs must know what steps to take to ensure that the negative impact has the least possible impact on the further operation of their business.

\section{Determinants of enterprise development}

The development process isa long-term phenomenon that operates in the economy and includes quantitative and qualitative changes. The quantitative changes include: production growth, investments, employment, employment structure, income, the size of the operating capital, and other economic quantities that exist in the quantitative sphere of the economy. In practice, the quantitative changes that occur most often result in qualitative changes (Komańda \& Klosa, 2020). According to the author of the article, the most important of them is the change in the organization of society. In sucha situation we can consider as the basic factors of economic development: human capital, entrepreneurship, land and raw materials, technical progress and investments. This phenomenon is particularly visible on the economic market in the first twenty years of the 
XXI century. Of course, this process is dominated by intensifying globalization processes, causing permanent market turbulence. This phenomenon leads to the emergence of new, previously unprecedented changes. Thus, we can distinguish many factors determining the development of economic activities, which may differ significantly or be practically identical.

Thus, we can see development asa qualitative phenomenon, which consists in introducing innovations (product, process, structural, organisational and management innovations, etc.). This effectively adapts the company to its environment (e.g. providinga competitive advantage). Growth, on the other hand, isa quantitative category and means an increase in the amount of resources increasing the scale of the enterprise's activity (e.g. leading to an increase in sales, increase in market share, increase in assets, or employment). A. Stabryła (2010) believes similarly, pointing out that development means the occurrence of qualitative changes, evaluated positively from the perspective of the objective they refer to. Other authors, however, draw attention to the complementary nature of qualitative and quantitative changes in the development process. J. Penc (2009) states that development isa targeted process of quantitative and qualitative changes (structural, technological, cultural, etc.) that showa permanent trend, favouring the survival and stability ofa given enterprise.

Therefore, it is difficult for us to createa single, comprehensive and, most importantly, universal definition of the company's development. After all, this concept is difficult for us to identify and interpret, let alone define. According to the author of the article, the main reason for these problems is the fact that in every economic organization that carries outa specific activity, the development may take place in completely different areas of the economy or will be associated with different goals. Of course, one can try to define economic development following M. Krezymon (2018) - this isa development taking place during the process of change, which may concerna part of the company or its whole and relate to all or one area of operation. The company's development can be considered as the elimination of developmental discrepancies, i.e. the so-called development gap or asa process of improving the place occupied by the company in its environment (Augustyńczyk, 2020). According to other researchers, development isa process based on values, cooperation and science. This leads to improvement and strengthening of the company strategy. This is done by simultaneously strengthening processes, strategies, cultures and people forming one company. This leads to an increase in the efficiency of the business unit. As elements of development we can distinguish here changes in the structure of systems, improvement of the existing system or its elements 
and introduction of innovative changes to the existing system (Glinka \& Pasieczny, 2015).

Development is also more and more often defined as quality, which is another factor in the company's development. The customer currently hasa wide range of the same or similar products or services that are offered by companies. Therefore, their quality should meet certain standards or be higher than customers' expectations. Quality isa good thanks to which an entrepreneur hasa possibility to build permanent, based on mutual trust, relations witha client and is one of the most important factors ofa company's development. The development can also refer to the desire to survive on the market, maintaining the chosen scale of production and form of activity. Then its determinant becomesa person or persons managing an economic unit. Their strategic, marketing and analytical activities lead to maintaining market stability (Mitek \& Micuła, 2013).

The author of the article believes that the determinants of the development of enterprises can be divided into two basic categories: factors influencing enterprises from the external environment and internal determinants usually created by the enterprise itself. Going this way and following J. Targalski (2014), the external factors include, among others:

- globalization of the economy,

- economic prosperity,

- situation on the foreign and domestic market,

- innovations,

- state fiscal policy and legal regulations,

- level of economic growth,

- free movement of goods and services.

The composition of the internal factors is:

- processes taking place in the company,

- material resources held,

- management efficiency,

- entrepreneurial personality,

- business partnerships,

- objective and strategy,

- human capital,

- quality,

- competitiveness of products and services.

Of course, analysing the above indicators, it is hard not to get the impression that we are moving to the macroeconomic level, while the considerations should concern the micro level (enterprises). However, the further argument does not, 
after all, concern economic development, which is studied more in economics than in management and quality sciences, but precisely the development of enterprises. This is, first of all, the result of the specificity of the economic market in the 21st century, whose turbulent determinants havea significant impact on the functioning of economic entities within its scope.

However, for the purposes of this article, the author, after analysing the literature and observing the economic processes taking place on the Polish economic market in recent years, has divided all these factors into five categories: economic, social, administrative/legal, cultural and management determinants. All of these can either be the driving force behinda company's development or, if they are omitted or misapplied, they can become the impetus fora company's downfall.

At the beginning it is worth noting that each of the categories contains specific aspects that are able to motivate or demotivate individual individuals to start their own company or not. However, in the opinion of the author of the article, the launch ofa particular enterprise will depend solely on the idea of this process ofa particular person. Moreover, it will depend on the personal qualities, knowledge, experience anda number of skills and competences, about which the author has already written ina separate study.

Table 1. Determinants/factors of enterprise development in Poland

\section{Economic factors}

All sources of external capital thata particular business is able to raise (certainly witha favourable offer this will be an incentive to run your own business)

1. Equity capital- cash or in-kind product contributed by the owner or co-owners that will facilitate the development or start-up of the business.

2. Foreign or debt capital, i.e. financing of the enterprise from various sources on the basis of contracts, for example: credit, leasing, bonds.

3. Grants and subsidies from the European Union.

\section{Social determinants}

In addition to the fact that owning their own business can provide the financial income needed, many people aspire to something more - they want to create jobs for themselves and their potential employees. The desire for self-fulfilment, independence, well-being or prestige can also fall into this category. Often, these factors playa major role in the decision to become self-employed.

Administrative/legal determinants

Over the last few years, the system that makes it possible to start upa business has become much simpler: 
- The amendment of the Act of 2 July 2004 on freedom of economic activity, which made it possible to registera business via the Internet.

\section{Cultural determinants}

The relationship betweena country's culture and the level and nature of entrepreneurship has long been the subject of research. For the purpose of the survey, areas of business management were identified that may be affected by cultural factors.

Management determinants

1. Entrepreneurial orientation.

2. Market orientation.

3. Human resource management model.

4. Styles of managing people.

5. Management methods and techniques

Source: own study

\section{Analysis of research results}

The main basis for the briefly described conclusions in the chapter (this is described in detail by the author of the article below) wasa study consisting in the assessment of national conditions for the development of entrepreneurship in the micro, small and medium-sized enterprise sector - based on the opinions of entrepreneurs and the analysis of actions taken. The main objective of the study was to identify factors/determinants that determine the development of economic entrepreneurship in Poland over the last 5 years. Author had to apply the following set of research methods:

1. Analysis of the subject literature - to systematize the language of concepts related to entrepreneurship and development.

2. Questionnaire (structured interview) with business owners - the main element of the research work was carried out in 2015 (first survey), 2017 (second survey) and at the turn of 2019/2020 (comparative survey) in 200 purposively selected enterprises from the SME sector, which are based in Poland and were established not earlier than 2010 (assessment of the size of the enterprise in the categories: micro, small, medium, was made on the basis of financial data - net income and balance sheet total, as well as the number of employees). It should be noted, however, that only 198 enterprises took part in the comparative research - one was liquidated and the other changed its owner, which disqualified it from further participation. The information and 
opinions obtained in this way referred to the current situation of the enterprise and the assessment of the enterprise's development in the last 5-year period ina few cases to the opinion on the prospects of the enterprise's development in the coming years.

Table 2. Characteristics of enterprises participating in the study

\begin{tabular}{c|c|c|c|c|c}
\hline \multicolumn{2}{c}{ size } & \multicolumn{2}{c}{ medium } \\
\hline \multicolumn{2}{c|}{ micro } & \multicolumn{2}{c}{70} & \\
\hline \multicolumn{7}{c|}{ location (according to the province where it is registered) } \\
\hline pomorskie & lódzkie & małopolskie & $\begin{array}{c}\text { kujawsko - } \\
\text { pomorskie }\end{array}$ & $\begin{array}{c}\text { zachodniopo- } \\
\text { morskie }\end{array}$ & $\begin{array}{c}\text { warmińsko - } \\
\text { mazurskie }\end{array}$ \\
\hline 71 & 13 & 17 & 47 & 23 & 29 \\
\hline services & transport & construction & hotel industry & food & Industry \\
\hline 45 & 33 & 29 & 19 & 39 & 35 \\
\hline
\end{tabular}

Unfortunately, due to financial and organisational limitations, the collected sample does not have the characteristics of the entire population (it should be 72 thousand entities). Therefore, the presented research results are nota complete set - they are the basis for extending the research process in the future - it isa pilot study for now. The author created the questionnaire himself. He chose entrepreneurs as respondents, because they have the greatest knowledge about their companies. The author was also interested in their approach to entrepreneurship, their motivation and their feelings. In this way the author was able to obtain the most suitable information for the purposes of the study. The author used the evaluation method to determine the determinants of entrepreneurship development and actions taken in this area, in the face of new economic challenges. Of course, the author agrees with the opinion that evaluation is always in some waya subjective method. However it is difficult to finda more objective research tool that would be simple enough to induce respondents to participate in the survey. To measure the analysed factors the author used the 
ordinal level (he also used Likter and Osgood scales). For variables measured on an ordinal scale we can calculate the dominant, i.e. the most frequent case. We can also determine the median, because we are able to rank the cases. On the other hand, the author based the measurement of quantitative factors on the quotient level. In turn, the author used Statistica version 12. anda Microsoft Excel spreadsheet to carry out statistical calculations.

Currently, there is no fixed list of factors of development of the SME sector. Its variability results from the fact that in various studies of enterprises, new factors determining significantly their development and growth processes are usually determined. An example of sucha factor is the so-called entrepreneurial orientation, which is an aggregation of the pursuit of implementing innovative solutions that refresh and improve the market offer, the ability to take the risk of implementing untested solutions and being more proactive than rivals in the use of market opportunities. Other variables of this type are market orientation, which is related to market monitoring and introduction of new business models. It may also be the introduction of human resource management models that are based on participation, commitment and activity.

To sum up,a survey with 200 business owners, which was launched in Poland over the last 5 years, allowed the author to collect data which, in his opinion, will allow him to try (this isa pilot study for the time being) to create the construction of the previously described measures of entrepreneurship development. These measures were used in the analysis as dependent variables, the effects of certain groups of factors.

On the basis of the results of the analysis of the individual components of entrepreneurship development, the author specified the names of the selected indicators/determinants and he extended the list of them with those he considered useful from the point of view of the general objective of the study in total he developed 9 indicators/determinants, based on initial methodological assumptions. According to the author of the study the indicators/determinants make it possible to assess the level of development of enterprises (direction and pace of changes) depending on selected factors of local and institutional environment, internal factors, level of achieved financial results, sources of financing.

Below (table 3), the author of the article presented the evaluation of indicators/ determinants of development of new and developing companies, made by their owners. It is noteworthy that in each subsequent time period (each year) this evaluation is better than that of the previous year. Most of the nine areas forming the national entrepreneurship determinants identified in this study were rated higher. The best rated areas include: 
- access to technical infrastructure - respondents highly evaluate the availability of telecommunications services for new and growing companies, and the costs associated with basic utilities (gas, water, electricity, sewage) are nota problem for tchem,

- the dynamics of the internal market - according to business owners, the Polish market of consumer goods and services and business-to-business is changing significantly from year to year,

- access to external financing - this is an area which is getting better and better evaluated by the respondents year after year and which does not significantly limit the commencement and development of activities in Poland.

In 2019 (and early 2020) a significant improvement, according to the respondents, took place in the following areas:

- entrepreneurship education at the level of higher education and lifelong learning,

- commercial and service infrastructure-the respondents better assessed the ease of obtaining good banking services and professional lawyers and accountants, as well as the ease of obtaining good subcontractors and consultants,

- cultural and social norms - the statements on cultural and social norms were best evaluated in this area in the context of emphasis on self-sufficiency and self-initiative and emphasizing personal responsibility in managing one's life.

In several cases, the ratings of entrepreneurs have decreased, which may indicatea more difficult situation in these areas. These include: burdens related to market openness, dealing with bureaucracy (regulations, consistency and predictability of taxes) and issues related to research and development for example, effectiveness of technology transfer, access to new knowledge, possibility of acquiring new technologies by young companies. What is important, almost $95 \%$ of the surveyed business owners indicated the facilitation of startinga business as an element that does not influence the decision to starta business - this probably testifies to the still prevailing fear of "Polish bureaucracy". This is probablya matter of already well-established stereotypes. The thesis of being guided by stereotypes was also confirmed by the fact that only $9 \%$ of the respondents pointed to the possibility of choosing simplified accounting asa factor influencing the decision to runa business.

Additionally, for the needs of the survey, areas of business management were identified, the functioning of which may be influenced by cultural factors respondents were asked how they react in difficult situations concerning the listed areas: 
- most business owners $(87 \%)$ stated that they react too emotionally to problematic situations,

- do not approach business issues with detachment (76\%),

- they make most business decisions not after thorough analysis and determination of the level of risk, but ona hunch (56\%).

However, we must also remember that all this information and opinions were collected before the pandemic - the author believes that currently, i.e. in Q2 and Q3 2021, the situation may have changed the opinion of the owners who took part in the survey.

Table 3. Assessment of designated indicators/determinants by respondents

\begin{tabular}{l|l|c|c|c}
\hline \multirow{2}{*}{ No } & \multicolumn{1}{|c|}{ indicators / determinants } & Poland & Poland & Poland \\
\cline { 3 - 5 } & & 2015 & 2017 & $2019 / 2020$ \\
\hline 1. & access to technical infrastructure & 71 & 96 & 137 \\
\hline 2. & the dynamics of the internal market & 73 & 93 & 128 \\
\hline 3. & access to external financing & 56 & 87 & 119 \\
\hline 4. & entrepreneurship education at the level of higher & 78 & 83 & 112 \\
\hline 5. & commercial and service infrastructure & & 76 & 99 \\
\hline 6. & cultural and social norms & 56 & 66 & 89 \\
\hline 7. & burdens related to market openness & 54 & 57 & 50 \\
\hline 8. & dealing with bureaucracy & 41 & 43 & 29 \\
\hline 9. & issues related to research and development & 14 & 25 & 19 \\
\hline
\end{tabular}

Source: own study

A very large number of data that the author obtained during the survey allowed to group and present them in two areas. The first area concerns behaviors related to the concept of entrepreneurship of their owners and their subjective opinion about their company. The second area is specific information related to the relations between variables, which are related to the management of the studied entities and their development and growth - these data are discussed and used in another study. 
In the first place, according to the author of the article, he must show the motives behind the decision to start his own company. As the main motive were indicated economic issues, which result from the desire to improve the financial situation (73\%). Next, the desire for self-fulfillment and fulfillment of life's desires (60\%), as well as the fear of unemployment $(49 \%)$, low income obtained in the previous work, persuasions of family and friends and the willingness to invest their financial resources. There were also voices about the willingness to spend free time, family traditions, as well as necessity - sudden loss of job or lack of suitable offers.A very important element connected with motivation to starta company and also with the development of the company are personality traits of entrepreneurs, which very often determine success in business. These include industriousness, as well as the knowledge resources necessary for making decisions and the risks associated with it, knowledge about the management of the company and the implementation of individual management functions. Also important were professional competences, gained in previous professional experience, as well as consistency in action and perseverance. The respondents considered creativity, responsibility or decision making skills to be less important. This surprised the author of the article (detailed distribution of answers related to motivation and personality traits is shown in figure 1).

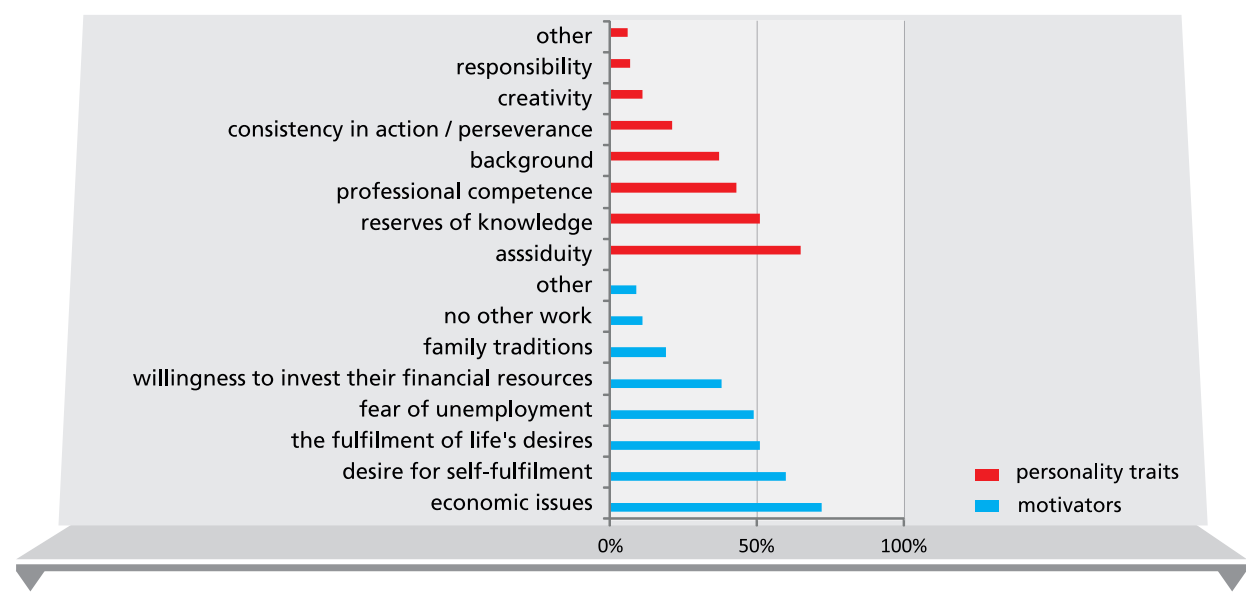

Figure 1. Motives for starting up your own business and personality traits that determine success in business

Source: own study 
In this part of the analysis of research results, the author decided to focus on the internal conditions of enterprise development, i.e. determinants related to the characteristics of enterprises, their management systems and actions taken by entrepreneurs. The obtained data and conclusions are certainly consistent with modern business models of enterprises, which in the era of knowledgebased economy, attach great importance to human capital, business cooperation and intense competitive competition. Taking into account the functioning of the surveyed enterprises in terms of the number of employees, served clients, the value of equity capital, the size of revenues, the author noted that the vast majority of respondents stated an improvement in the situation in their enterprises. Most people referred to the increase in the value of net revenues - for $72 \%$ of entities and to the improvement in the competitive position of entrepreneurs - $66 \%$ of entities.

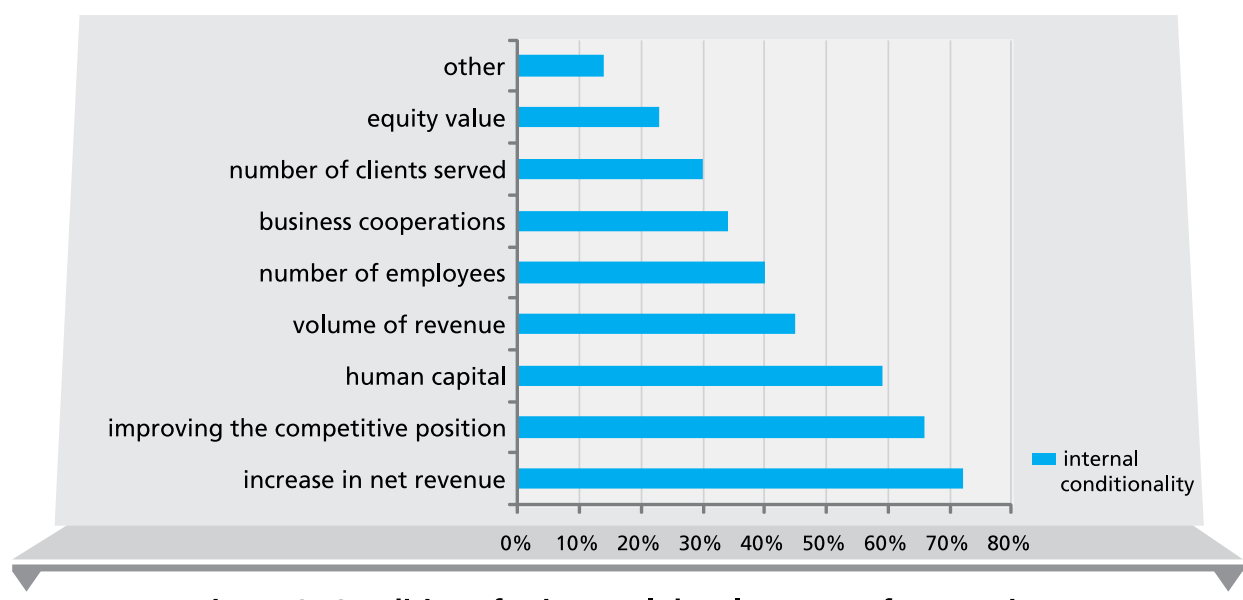

Figure 2. Conditions for internal development of enterprises

Source: own study

The internal conditions of conducting business activity may also include the impact of actions taken by entrepreneurs in relation to their competitors during the fight for the client. The analysis of the collected data shows that there is quitea lot of competition on the market, which was evaluated at the level of 4.6 points ona 5 -stage scale and which is noticed by $89 \%$ of the surveyed persons. Respondents, in order to win and keep their customers, most often bet on 
nice service, high quality of goods, products and services and working hours adjusted to customers' needs. They try to influence purchasing decisions by applying discounts. Depending on the industry and size of their business they also provide free transport and additional gratuities in the form of so-called gifts. They also make it possible to make purchases in installments and offer loyalty cards.

Obviously, the biggest challenge may be to obtain the necessary financial resources. The analysis of the data after the survey showed that almost $80 \%$ of the surveyed companies used their own capital. Unfortunately, due to the transition period, associated with the implementation ofa new programming period of EU funds in Poland, the respondents did not have the opportunity to use this option. However, nearly $70 \%$ of the surveyed respondents indicated that they were interested in this form of support in the future.

In many cases the barrier is also the inability to organize cooperation with business partners, due to organizational and technological immaturity.

But on the basis of the collected material, the author claims that among the surveyed group of Polish entrepreneurs, the awareness of the importance of human capital and its optimal management in order to get the most out of their employees is quite common. They know that they have to get as much of their employees as possible to succeed. They try to build commitment of the team, while they strive for $28.4 \%$ of teamwork, cooperation and care about building an integrated team. They know that in the 21st century this isa key determinant of the market success of their companies. Unfortunately, the lack of an appropriate organizational culture and failure to implement programs for the company's most important employees makes it impossible for them to retain key employees. They also cannot find new, equally talented employees in their place. What should be the foundation of the new order in the company? It turns out that the owners of the surveyed entities are perfectly aware of it - figure 3 .

As we can see it is above all cooperation that bypasses existing structures and divisions. In many companies, a very big problem is the separate functioning of people responsible for business, and separate for technology. This effectively makes it difficult to take advantage of the opportunities brought about by economic changes. Of course, it is also necessary to have clear leadership, which does not run away from difficult decisions and treats subordinates ina partner way. And most importantly, you need to define your capabilities and establish strategies to avoid falling behind. After all, the key success factor is not technology per se, but people who can use it effectively. But why don't we do it? Don't we want to use people's potential asa weapon to fight new challenges? 


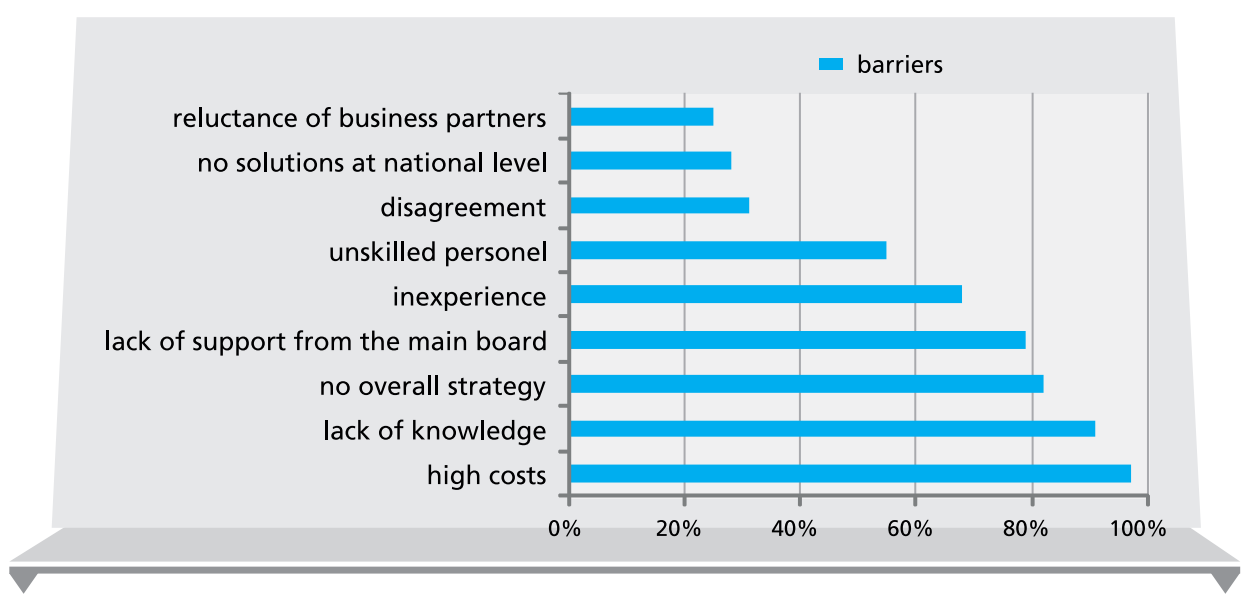

Figure 3. Barriers to optimal human capital management

Source: own study

Don't we forget about the necessity of system solutions, starting with changes in organizational structures and cultures. These questions are undoubtedly the starting point for identifying innovative tools of human capital management in new economic conditions.

\section{Conclusion}

In this article the author has attempted to identify the factors / determinants of the development of entrepreneurship, which are most important from the point of view of entrepreneurs themselves. In his research he paid special attention to external and internal conditions.

Certainly, the financial aspect had the greatest influence on making the decision about "own business" among the surveyed respondents, and only then the pursuit of self-fulfilment and the desire to be independent. However, the main sources of financing for the development of companies from the research group were considered to be own resources. This confirms the common conviction about piling up barriers on the way to acquiring foreign capital, i.e. loans or financial resources from loan funds. For the respondents, the development of the companies turned out to be conditioned also by acquiring and, what is important, retaining clients, which resulted in 
indicating many implemented actions that are to bea guarantee of success in this respect.

Moreover, from the collected empirical material it appeared that entrepreneurs saw the importance for the development and success of many of the analyzed internal factors - they attributed great importance to innovative management methods and human capital. They also did not forget about increased competitive competition, in the face of market saturation with entities of similar size, which have similar or even identical products or services in their offer. Certainly, an important factor connected with the development of business activity is the owner's person - his personality traits of entrepreneurs, for example professional competence or consistency in action.

According to the author, we can assume that the determinants of enterprise development and entrepreneurship itself will becomea permanent element of management (if they are not already), just like physical assets, organizational structures, strategies, processes, systems, financial or information resources. On the other hand, looking at the permanent changes which are constantly taking place in the economy, the determinants of management in the 21st century will change - all the more so in the face of the fourth industrial revolution, connected with automation, data exchange and artificial intelligence. Therefore, it is necessary to adapt management to new conditions and to eliminate new barriers that stand in the way of optimal development of enterprises. In science, on the other hand, it is hoped that the need to develop these and new conceptual frameworks and methods to study these factors will not disappear, and the research presented in this paper is heading in the right direction.

To sum up, according to the author of the article, the conditions for the creation and development of enterprises in Poland against the background of economies focused on innovation are not the best.

However, there isa basis for optimism for the future, as most of the nine areas that form the primary basis for the identification of indicators/determinants of SME firm development in Poland, in this study, were rated positively by respondents. Unfortunately, all of the results of the survey are for the period up to 2020 and, in the author's opinion, reflecta very good economic situation and good situation on the labour market. This makes it easier to see the chances of setting upa company in their environment and at the same time less afraid of failure. We can only hope that in the new economic landscape, the landscape after the COVID-19 pandemic, the mood but also the actual state of the existing economy will also encourage optimism. Certainly, in connection with the dynamic changes taking place on the economic markets and the growing demand 
for information on the determinants of development and building competitive advantage of the SME sector, the author of the article plans to implement the described study ona larger group of entrepreneurs and their enterprises so that the results obtained are adequate for the entire population..

\section{Summary}

Factors determining the development of SMEs in Poland in 2015-2020

The main objective of the article is an attempt to identify factors/ determinants conditioning the development of enterprises in Poland in recent years. The author will also try to indicate the dominant behaviours related to the notion of entrepreneurship among the owners of the enterprises under study. In addition to the literature analysis, the author chosea survey in the form ofa structured interview with business owners as another research method - the survey was carried out in 2015 and 2017 and in 2019/2020 in 200 purposively selected enterprises from the SME sector, which are based in Poland and were established in the last 5 years. After the analysis of the literature and the results of the conducted survey, obviously bearing in mind its pilot character, the author clarified the names of the selected indicators/determinants and expanded their list by those he considered useful from the point of view of the general purpose of the survey - 9 indicators/ determinants. In the author's opinion, the developed indicators/ determinants make it possible to assess the level of enterprise development (direction and pace of changes) depending on selected factors of the local and institutional environment, internal factors, the level of achieved financial results, sources of financing.

Keywords: entrepreneurship, entrepreneurship development, determinants / factors of enterprise development.

\section{Streszczenie}

\section{Czynniki determinujące rozwój przedsiębiorstw z sektora MŚP w Polscew latach 2015-2020}

Głównym celem artykułu jest próba identyfikacji czynników/ determinantów warunkujących rozwój przedsiębiorstw i przedsiębiorczości w Polsce na przestrzeni ostatnich lat. 
Autor postara się również wskazać dominujące zachowania związanez pojęciem przedsiębiorczośću właścicieli badanych przedsiębiorstw. Poza analizą literatury, autor jako kolejną metodę badawczą wybrał ankietęw postaci wywiadu ustrukturalizowanegoz właścicielami przedsiębiorstw - badanie zostało przeprowadzonew roku $2015 \mathrm{i} 2017$ oraz na przełomie 2019 i 2020 roku w 200 celowo dobranych przedsiębiorstwach z sektora MŚP, które mają siedzibę w Polsce i powstały w ostatnich 5 latach. Po analizie literaturyi wyników prowadzonego badania, oczywiście mając na uwadze jego pilotażowy charakter, autor doprecyzował nazwy wybranych wskaźników/determinantów oraz poszerzył ich listę o takie, które uznał za przydatne z punktu widzenia ogólnego celu badania - 9 wskaźników/determinantów. Zdaniem autora opracowane wskaźniki/determinanty umożliwiają określenie oceny poziomu rozwoju przedsiębiorstw (kierunkui tempa zmian) w zależności od wybranych czynników otoczenia lokalnegoi instytucjonalnego, czynników wewnętrznych czy poziomu osiąganych wyników finansowych, źródeł finansowania.

\section{Słowa}

kluczowe: przedsiębiorczość, rozwój przedsiębiorczości, determinanty/czynniki rozwoju przedsiębiorstw.

JEL

Classification: M12, M13, O11

\section{References}

Augustyńczyk, J. (2020). Entrepreneurship in selected economic theories. [w] Wspótczesne problemu ekonomicznew badaniach młodych naukowców. Teriai praktyka (red.) E. Gruszewska, t. 4, (pp. 28-42). Białystok: Wydawnictwo Uniwersytetu w Białymstoku.

Białasiewicz, M. (2008). Entrepreneurship - a desirable competence. Studiai Prace Wydziału Nauk Ekonomicznych i Zarządzania., Vol. 1 (pp. 7-16). Szczecin: Wydawnictwo Uniwersytetu Szczecińskiego.

Glinka, B., Pasieczny, J. (2015). Tworzenie przedsiębiorstwa. Szanse, realizacja, rozwój. Warszawa: Wydawnictwo Uniwersytetu Warszawskiego.

Kaliszczak, L., Sieradzka K. (2020). Shaping entrepreneurial attitudes of students towards contemporary development challenges. Przedsiębiorczość - Edukacja, 16(2), pp. 99-114. 
Komańda, M, Klosa E. (2020). Corporate approaches to information sharing in supply chain risk management. ZN WSH Zarządzanie, 21(2), pp. 137-151.

Krezymon, M. (2018). Determinants of SME enterprise development. Wspótczesne Problemy Ekonomiczne, Vol. 18, No 2, pp. 23-31.

Łochnicka, D. (2016). Przedsiębiorczość pracownicza i jej wptyw na efektywność organizacji. Łódź: Wydawnictwo Uniwersytetu Łódzkiego.

Mitek, A., Micuła, I. (2012). Wspótczesne determinanty rozwoju przedsiębiorstw prywatnych. Wspótczesne wyzwania gospodarowania i zarzadzania. Warszawa: PWE.

O'Rourke, P. J. (2009). Adam Smith. Bogactwo narodów. Warszawa: MUZA Press.

Penc, J. (2009). Innowacje $i$ zmiany $w$ firmie - transformacja $i$ kierowanie rozwojem przedsiębiorstwa. Warszawa: Placet.

Say, J. B. (2012). Revolutionary, entreprenuer, economist. New York: Routlegde Press.

Shane, S., Venkataraman, S. (2003).A General Theory of Entrepreneurship. the Individual - Opportunity Nexus. Northampton: Edward Elgar Pub.

Stabryła, A. (2010). Zarzadzanie strategiczne w teorii $i$ praktyce firmy. Warszawa: PWN.

Targalski, J. (2014). Przedsiębiorczość $i$ zarządzanie małym i średnim przedsiębiorstwem. Warszawa: Difin.

Thornton, M. (2007). Richard Cantillon and the Discovery of Opportunity Cost. History of Political Economy, Vol 39, No 1, pp. 97-120. 